\title{
Multichannel Seismic Imaging of the Rivera Plate Subduction at the Seismogenic Jalisco Block Area (Western Mexican Margin)
}

\author{
Rafael Bartolome, ${ }^{1}$ (D) Estefanía Górriz,,${ }^{1,7}$ Juanjo Dañobeitia, ${ }^{2}$ Diego Cordoba, ${ }^{3}$ David Martí, ${ }^{4}$ \\ Alejandra L. Cameselle, ${ }^{1}$ Francisco Núñez-Cornú, ${ }^{5}$ William L. Bandy, ${ }^{6}$ Carlos A. Mortera-Gutiérrez, ${ }^{6}$ \\ Diana Nuñez, ${ }^{5}$ Arturo Castellón, ${ }^{2}$ and Jose Luis Alonso ${ }^{2}$
}

\begin{abstract}
During the TSUJAL marine geophysical survey, conducted in February and March 2014, Spanish, Mexican and British scientists and technicians explored the western margin of Mexico, considered one of the most active seismic zones in America. This work aims to characterize the internal structure of the subduction zone of the Rivera plate beneath the North American plate in the offshore part of the Jalisco Block, to link the geodynamic and the recent tectonic deformation occurring there with the possible generation of tsunamis and earthquakes. For this purpose, it has been carried out acquisition, processing and geological interpretation of a multichannel seismic reflection profile running perpendicular to the margin. Crustal images show an oceanic domain, dominated by subduction-accretion along the lower slope of the margin with a subparallel sediment thickness of up to $1.6 \mathrm{~s}$ two-way travel time (approx. $2 \mathrm{~km}$ ) in the Middle American Trench. Further, from these data the region appears to be prone to giant earthquake production. The top of the oceanic crust (intraplate reflector) is very well imaged. It is almost continuous along the profile with a gentle dip $\left(<10^{\circ}\right)$; however, it is disrupted by normal faulting resulting from the bending of the plate during subduction. The continental crust presents a well-developed accretionary prism consisting of highly deformed sediments with prominent slumping towards the trench that may be the result of past tsunamis. Also, a bottom simulating reflector (BSR) is identified in the first half a second (twtt) of the section. High amplitude reflections at around 7-8 s twtt clearly image a discontinuous Moho, defining a very gentle dipping subduction plane.
\end{abstract}

1 Instituto de Ciencias del Mar-CSIC, P. Marítimo de la Barceloneta 37-49, 08003 Barcelona, Spain. E-mail: rafael@icm.csic.es

2 Unidad de Tecnología Marina-CSIC, P. Marítimo de la Barceloneta 37-49, 08003 Barcelona, Spain.

3 Universidad Complutense de Madrid, Ciudad Universitaria, Plaza Ciencias, s/n, 28040 Madrid, Spain.

4 Instituto de Ciencias de la Tierra Jaume Almera, C/Lluis Solé Sabaris s/n, 08028 Barcelona, Spain.

5 Centro Universitario de la Costa (CUC), Av. Universidad 203, Del. Ixtapa, 48280 Puerto Vallarta, Mexico.

6 Instituto de Geofísica, UNAM, Ciudad Universitaria, Delegación Coyoacán, C.P. 04510 México, DF, Mexico.

7 Present Address: University of Barcelona, Marti i Franques $\mathrm{s} / \mathrm{n}, 08028$ Barcelona, Spain.
Key words: Jalisco Block, Mexico, Rivera plate, crustal structure, seismic imaging, subduction, earthquake, tsunami, BSR, gas hydrate, trench infill.

\section{Introduction}

Subduction is the geodynamic process by which one tectonic plate converges with and slides beneath another tectonic plate, finally sinking into the mantle; its motion being driven by the higher density (colder) of the descending oceanic slab with respect to the surrounding mantle asthenosphere. At depths between 80 and $120 \mathrm{~km}$, oceanic basalt is converted to eclogite, which further increases the slab density and the downward force. The interplate coupling is weaker for older plates (KANAMORI 1977), and the friction along the main thrust interface increases with increasing velocity of the subducting lithosphere. As a consequence, high rates of earthquakes, defining the Wadati-Benioff zone, and tsunamis occur in subduction zones where the subducting slab is old. The cold environment of the slab depresses the local geothermal gradient and increases the portion of the Earth deforming in a brittle manner.

Recent research based mainly on the 2011 Tohoku event has suggested that the generation of huge tsunamis may require the release of gravitational energy as well as elastic energy (GEORGE et al. 2011). This gravitational energy comprises primarily crustal wedge uplift. When a megathrust earthquake occurs, gravitational energy is discharged by the formation of giant landslides or the rigid motion of a crustal block sliding though a normal fault or splay faults that may 
produce the subsequent tsunami generation (GRILLI et al. 2012). Therefore, monitoring bathymetry and gravity before and after such events, especially involving the crustal wedge, will help scientists to understand the phenomenology and estimate the associated risks. As a consequence, there is an obvious need to reevaluate earthquake and tsunami hazard assessments based on these data.

The Rivera plate is particularly a region where large earthquakes have occurred with very destructive consequences, including the generation of big tsunamis, e.g., the $\mathrm{Mw}>8.01932$ and 1995, demonstrating that the Jalisco Block is a zone of high seismic potential as a consequence of the subduction dynamics. Research in subduction zones includes several geophysical techniques, such as multichannel reflection seismic and high-resolution bathymetry.

The main objective of this work is to characterize the internal structure of the Rivera Subduction Zone in the Jalisco Block area to understand the geodynamic and the recent tectonic deformation. A key point in the definition of sources (faults, landslides) is to conduct a study of the relationship between superficial, including the seafloor structure, and depth structures where the lithosphere subducts and major seismic activity occurs. Growing understanding of subduction dynamics suggests that crustal deformation near subduction zones will have to be monitored and investigated in detail to obtain the information needed for tsunami risk estimation. Understanding the lateral and vertical extent of the boundaries of the subducting slab will constrain plate tectonic configurations and the timing of events in the western Mexican margin.

To understand the processes involved in the subduction of the Rivera plate and to solve the lack of seismic imaging and bathymetry information, a multidisciplinary geophysical approach is needed to characterize the area from the surface, to the deep zones. This information will be of paramount importance for future seismic hazard assessment. We describe the acquisition, processing and the geological crustal interpretation of a multichannel seismic marine profile running perpendicular to the coast at the Jalisco Block area. These data, of unprecedented quality, were recently acquired in the framework of the TSUJAL (TSU-nami and JAL-isco) project (Bartolomé et al.
2015). The unprecedented quality of the data provides a brand new seismic image of the internal structure of the Rivera Subduction Zone beneath the North American plate from which the geodynamic context can be inferred. Furthermore, the characteristics of the interaction between the Jalisco Block and the sediments thickness of the trench clearly indicate the probability of the occurrence of large earthquake.

\section{Geological Setting}

The western margin of Mexico is an active region displaying ongoing tectonic plate interactions. Seafloor spreading is occurring along the northern most segment of the East Pacific Rise (EPR), commonly referred to as the Rivera Rise, which bounds the Rivera plate to the west. Spreading rates ranges from $5.3 \mathrm{~cm} /$ year at the northern end of the rise to $7.3 \mathrm{~cm} /$ year at it southern end (e.g., BANDY 1992). On its eastern boundary, the Rivera plate subducts beneath the North American plate (NA) in the Middle American Trench (MAT). South of the Colima Graben, the Cocos plate subducts beneath the NA at the MAT. The MAT extends from the Tres Marias Islands, located south of the Gulf of California at $21^{\circ} \mathrm{N}$, southward along the Mexican coast for a distance of approximately of $3000 \mathrm{~km}$. The continental shelf and slope along the MAT is quite narrow, being between 40 and $60 \mathrm{~km}$. The southern boundary of the Rivera plate consists of two distinct segments. The western segment, west of $106.25^{\circ} \mathrm{W}$, is the Rivera Transform zone, which is an active transform fault separating the Rivera and Pacific plates. The eastern segment, east of $106.25^{\circ} \mathrm{W}$, is the poorly defined Rivera-Cocos plate boundary. Two closely spaced plate triple junction lie along this boundary, namely, the Pacific-Rivera-Cocos triple junction at its intersection with the EPR to the west and the Rivera-Cocos-North American triple junction at its intersection with the MAT. Several proposals exist as to the nature of this boundary. These include a hinge fault (i.e., pure vertical motion between the plates, NiXON 1982), a southwest propagating divergent boundary (BANDY 1992), and a diffuse left-lateral transform boundary (DeMETs and WILSON 1997). The location of this boundary beneath NA is also being 
debated. Nixon (1982) proposed that it extends beneath the southern and northern Colima rifts (Fig. 1). BANDY (1992) similarly proposed that it extends beneath the southern Colima rift but instead proposed that it was located west of the northern Colima rift. The gravity study of BANDY et al. (1995) supported the proposal of BANDY (1992), however, it raised the possibility that the tear zone between the Rivera and Cocos plates beneath NA could extend to the area beneath the northern Colima rift (i.e., to the NE the boundary was a wide tear zone). The proposal of a wide tear zone between the subducted Rivera and Cocos plates beneath the northern Colima Graben and adjacent areas produced by divergence between the Rivera and Cocos plates is supported by the seismic studies of YANG et al. (2009), Leon Soto et al. (2009) and OchoA-Chavez et al. (2015). More recently, Alvarez and Yutsis (2015) also place the boundary beneath the southern Colima rift. In contrast, DeMETs and Wilson (1997) placed the boundary north of the El Gordo graben/southern Colima rift (Fig. 1).

The area has also been subjected to the effects of at least two Ridge-Trench collisions. The first collision occurred at around 10 Ma when the EPR collided with the trench off the southern tip of Baja California, the collision most likely was responsible for the separation

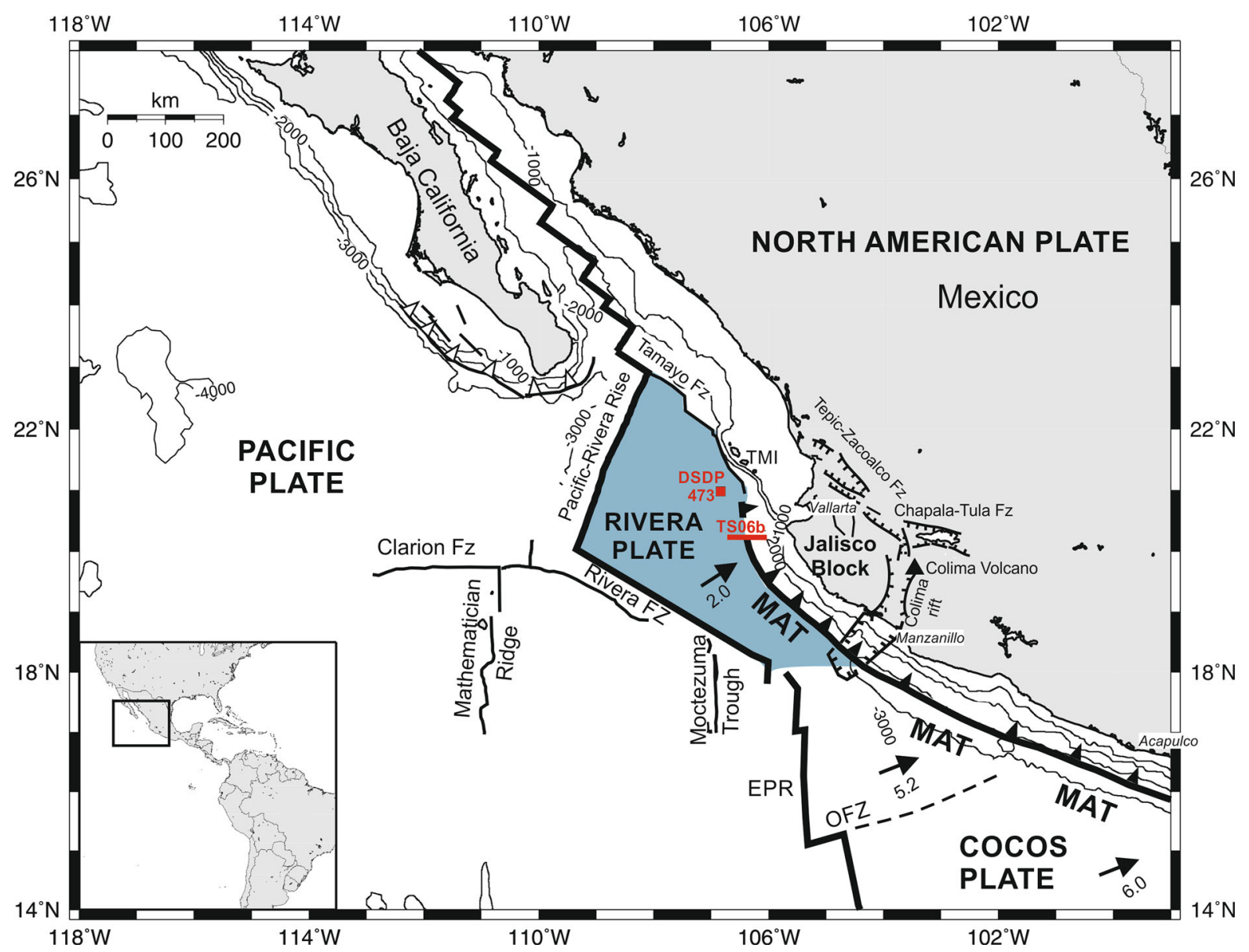

Figure 1

Location map of western Mexico. Four lithospheric plates act in the area: Pacific, Rivera, Cocos and North America. Blue area highlights the area of the Rivera plate. Arrows indicate relative convergence rates ( $\mathrm{cm} /$ year) between the oceanic and continental plates (PARDO and SUÁREZ 1995). Red line indicates the location of MCS section TS06b. Red square shows the DSDP drill 473 south Tres Marias Islands. TMI Tres Marias Islands, MAT Middle America Trench, EPR East Pacific Rise 
of the Rivera plate from the rest of the plate to the south and the initiation of slab windowing between the Rivera and Cocos plates (e.g., KLITGORD and MAMMERICKX 1982; BANDY 1992). The second collision occurred at around $2 \mathrm{Ma}$ when the northward propagating segment of the EPR collided with the MAT near Manzanillo/Chamela (BANDY 1992; LonSDALE 1995; Michaud et al. 2000, 2001; Peláez Gaviria et al. 2013). The effects of the most recent collision in the Jalisco/ Colima area have been largely unaddressed in the literature and deserve more attention.

The Rivera plate began to separate from the Cocos plate at about $10 \mathrm{Ma}$ (DeMets and Traylen 2000) as evidenced by spreading velocities along the East Pacific Rise and Mathematician Ridge. Several models exist for the Rivera-North America Euler vector (e.g., Minster and Jordan 1979; Bandy and Pardo 1994; DeMets et al. 1994, 2010; Lonsdale 1995; DeMets and Wilson 1997; Bandy et al. 1997; Argus et al. 2010; SuÁrez et al. 2013). These models differ somewhat, however, almost all indicate that the convergence rate between the Rivera and North American plate decreases northward along the MAT [averaging about $2-3 \mathrm{~cm} / y e a r$, which is slower than the adjacent Cocos plate (5-8 cm/year)] and becomes highly oblique north of $20^{\circ} \mathrm{N}$ (see discussion by Kostoglodov and BAndy 1995). Rivera plate subduction is characterized by a steeper angle and more northerly trajectory than the adjacent Cocos plate, with a dip angle increasing at depths around $100 \mathrm{~km}$ (e.g., Bandy 1992; PARdo and SuÁrez 1995).

A summary of DSDP site, 473 results and interpretations of a $287 \mathrm{~m}$ long drill obtained on the Rivera plate, south of Tres Marias Islands, indicates that oldest sediments are 6-6.5 Ma (Upper Miocene) and no older than $8 \mathrm{Ma}$ with igneous rocks present at the bottom of the core. Moreover, KLITGORD and MAMMERICKX (1982) published that the lithosphere of the Rivera plate consumed at the trench dates as late as Miocene (approx. $9 \mathrm{Ma}$ ), whereas the Cocos crust near the Rivera plate is $10 \mathrm{Ma}$ and progressively becomes older to the SE, being $25 \mathrm{Ma}$ old at $90^{\circ} \mathrm{W}$. Terrigenous clay deposited in the early Pliocene to Quaternary and calcareous claystone deposited during early Pliocene are separated by a strong seismic reflector from the Upper Miocene sediments in the core. Sediments are unexpectedly terrigenous despite the distance from land and the MAT. Sediment accumulation rates are $40 \mathrm{~m} /$ million years for the last 3 million years and $20 \mathrm{~m} /$ million years from 3 to 6.5 million years. Sediment velocities are $1.5-1.6 \mathrm{~km} / \mathrm{s}$ increasing to $1.98 \mathrm{~km} / \mathrm{s}$ at the basal sediments. Igneous rocks below the sediments are mainly massive, altered diabase with a density of $2.7 \mathrm{~g} / \mathrm{cm}^{3}$ and a velocity of $5.2-5.3 \mathrm{~km} / \mathrm{s}$, but a fragment of pillow basalt was found at the bottom of the drill.

The margin along the Middle America trench from the Tres Marias Islands to the Manzanillo Area $\left(18^{\circ} \mathrm{N}\right.$, $104^{\circ} \mathrm{W}$ ) was uplifted and emergent before the late Miocene. The margin started to subside during the upper Miocene-lower Pliocene (coincident with the initial formation of the Rivera plate as an independent plate) and continued to subside at least until the Pliocene-Quaternary limit (Mercier de LePinay et al. 1997). From the Pliocene-Quaternary limit (approx. $2.5 \mathrm{Ma}$ ), the Manzanillo area continue subsiding whereas the Tres Marias Islands began to be uplifted (McCloy et al. 1988). Regional subsidence of an active margin is generally related to tectonic erosion, and therefore, such long-term subduction erosion regimen for the Manzanillo area implies trench retreat along the margin (Mercier de Lepinay et al. 1997). Recent overview of RAMírEZ-HERRERA et al. (2011) confirm that, although spatial and temporal variability exists, coastal subsidence is occurring at the southern Colima Graben and the Guerrero seismic gap near Acapulco, whereas coastal uplift is occurring between Puerto Vallarta and Manzanillo and along the coast south of the Colima/El Gordo Graben until Lazaro Cardenas, located southeast of Acapulco.

The Jalisco Block of western Mexico is generally considered as part of the NA plate; however, it may have some degree of independent motion. There are active faults along the Tepic-Zacoalco and Colima rifts in southwestern Mexico that some authors considered to be related to Rivera-North America tectonics (Allan 1986; Johnson and Harrison 1989; Allan et al. 1991, Fig. 1). However, BANDY and PARDO (1994) found, based on a plate kinematic analysis that if the Jalisco Block is moving relative to $\mathrm{NA}$, its motion must be less than $1 \mathrm{~cm} /$ year. Consistent with this result, Selvans et al. (2011) find a slow motion of $2 \mathrm{~mm} / \mathrm{year}$ to the southwest for the Jalisco Block relative to NA in a recent GPS 
campaign conducted near the triple junction near Guadalajara. This motion may be compatible with a tearing of the Jalisco Block away from NA, however, the authors point out that the motion could be related to the behavior of the earthquake cycle for this margin and if so, the Jalisco Block may not be an independent crustal block.

Recent studies also evidence gas hydrates (MINSHULl et al. 2005; BARTOLOME et al. 2011; BANDY and Mortera GutiÉrRez 2012) in the form of bottom simulating reflectors (BSR) on multichannel seismic reflection profile located in the continental slope area of the northern part of the Jalisco Subduction Zone, off Puerto Vallarta, between $20^{\circ}$ and $20.5^{\circ} \mathrm{N}$, as well as off Manzanillo. Thus, there is evidence to suggest that the Pacific margin of Mexico may contain significant reserves of hydrocarbons in form of gas hydrates.

\section{Earthquake History of the Jalisco Region}

The macro seismic history of the Jalisco region dates back to the year 1544, and is considered one of the most active seismic zones in North America. In the last 120 years, ten major earthquakes were reported with $\mathrm{Ms} \geq 7.5$, including the destructive events occurring on the 3rd and 18th June 1932 with $\mathrm{Ms}=8.2$ and 7.8, respectively, and one with a magnitude of 8.0 occurring in 1995, all of them located offshore Jalisco. The 1932 event had a maximum tsunami run-up height of $3 \mathrm{~m}$ (Окаl and BorRERo 2011) and caused 400 casualties, whereas the 1995 earthquake triggered a tsunami with a runup height of $5.1 \mathrm{~m}$ that affected a $200 \mathrm{~km}$ long stretch of coast with severe damage confined to areas with shallow shoreline topography (Fig. 2). Considering that the area of rupture of the 1995 event spans only the southern half of the area proposed for the 1932 events (NuÑEZ-CoRnú et al. 2004) and the 77 years recurrence time estimated by SINGH et al. (1985) for earthquakes similar to the 1932 event on the coast of Jalisco, which includes the Bay of Banderas where Puerto Vallarta is located, the northern Jalisco coastal area is a zone of high seismic hazard potential and known as Vallarta Gap (YAGr et al. 2004).

Moreover, not only do earthquakes associated with subduction processes occur in the region, but also large intraplate earthquakes take place, such as the historical events of December 27, 1568 and

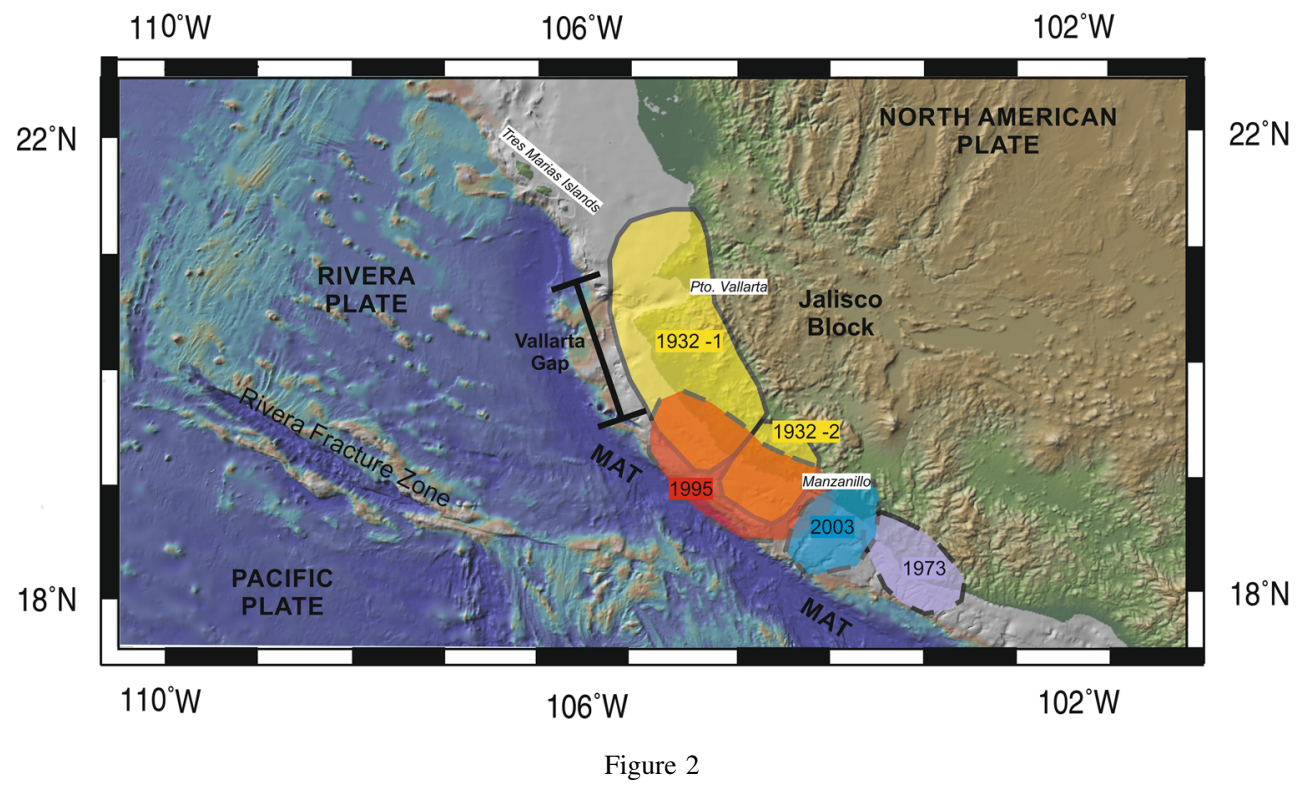

Approximate rupture areas for the two 1932 earthquakes (Mw 8.2 and Mw 7.8), 1973 (Mw 7.6), 1995 (Mw 8.0) from ANDREws et al. (2011) and 2003 earthquake (Mw 7.4) from the SSN (Mexican Servicio Sismológico Nacional). The 1932 events are shown with a solid line, while the 1973, 1995 and 2003 events are shown with a dashed line. The Vallarta Gap shows the expected future rupture area offshore the Jalisco Block 
February 11, 1872. However, there is a debate concerning the interplate (NunEz-CORNu et al. 2011) versus intraplate (ANDREws et al. 2011; QuintanAR RoBLES et al. 2011) origin of the Armería earthquake (Mw 7.4) of 2003, located near the diffuse triple junction between the Cocos, Rivera and NA plates.

Previous studies have shown some seismic images and models of the Rivera plate subducting under Mexico mainland. But in terms of seismic reflection data, a few single channel seismic profiles (BourGoIs and Michaud 1991; Khutorskoy et al. 1994; Michaud et al. 1996), one threefold profile (BANDY et al. 2005), several threefold profiles acquired in the Rivera transform zone (BANDY et al. 2011), and five multichannel analog seismic data acquired in 1996 during the CORTES project (BARTOLOME et al. 2011; DAÑobeitia et al. 1997, Fig. 3) are available in the literature. These data show active shallow strike-slip tectonics and a subsidence in the upper continental slope area at $18.5^{\circ} \mathrm{N}$, and the subducting Rivera plate crustal structure has been well identified near Puerto Vallarta at $21^{\circ} \mathrm{N}$. Little is known about the depth and structure of the plate underneath the Jalisco margin at north of $20^{\circ} \mathrm{N}$ and the paths of the water transported within the subducting oceanic lithosphere into the Earth's interior, water that affects intraslab earthquakes and arc magmatism.

\section{Data and Methods}

The data used in this study consist of multibeam bathymetric data collected in the Rivera, Cocos and NA plate offshore of the Jalisco Block, and one $65.5 \mathrm{~km}$ long, ESE-WNW oriented, multichannel seismic reflection profile, TS06b, running almost perpendicular to the Rivera Subduction Zone that was collected during the TSUJAL project (Fig. 3). The experiment took place onboard the $90 \mathrm{~m}$ long RRS JAMES COOK from the National Environmental Research Council (NERC) between February 17 and March 19, 2014. The ship includes a hull mounted water mapping system composed by a Kongsberg EM120 and Kongsberg EM710 multibeam echosounders, and the raw data were processed using the CARIS software (v. 8.1) while onboard by ICM technicians to produce a $80 \times 80 \mathrm{~m}$ grid of
Figure 3

Up 3D seafloor topography map of the western Mexican margin represented with a six times exaggeration vertical. TSUJAL highresolution bathymetry at $80 \mathrm{~m} \times 80 \mathrm{~m}$ grid space is superimposed to a background SANDwell and SMITH (2009) bathymetry with a $20 \%$ transparency. Red square indicates the area of Fig. $3 \mathrm{~b}$. Middle TSUJAL high-resolution bathymetry acquired offshore the Jalisco Block with the location of MCS profile TS06b and DSDP site 73 in red, and CORTES MCS sections in white (BARTOLOME et al. 2011) used in this work to help the interpretation. Vertical Exaggeration: 6. Down Synthetic bathymetric profile of TS06b in red, extended until the coast, showing the margin imaged by the multichannel seismic profile

bathymetric values. One Expendable Bathy Thermographs (XBT) per day was launched during the survey to measure water velocity profile and whose values have been integrated into the echosounder acquisition program.

Multichannel seismic data were acquired aboard the RRS James Cook using, for the first time, the $6 \mathrm{~km}$ long digital streamer belonging to the Spanish RV Sarmiento de Gamboa (BARTOLOMÉ et al. 2015; NúñEz-CoRnú et al. 2016; Dañobeitia et al. 2015), in the framework of a bilateral barter agreement between the National Environmental Research Council (NERC) and Consejo Superior de Investigaciones Cientificas (CSIC), thanks to the European research alliance OFEG (Ocean Facility Exchange Group). The hydrophone streamer was deployed at $10 \mathrm{~m}$ depth with 468 active channels (5850 m length) separated $12.5 \mathrm{~m}$ apart. CMP distance is $6.25 \mathrm{~m}$ and allows a CMP nominal fold of 58-59 traces. The source airgun arrays were designed using Gundalf ${ }^{\circledR}$ commercial software to maximize the energy concentrated at the lowest frequency range. The arrays were towed from the center of the stern to the port and starboard sides getting a symmetrical configuration from the streamer. The shooting interval was chosen to be $50 \mathrm{~m}$ as a compromise between maximum redundancy of data (CMP fold) and the capacity of the air compressors. Source array was composed by 12 guns divided in 4 subarrays of 3 guns, employing 3540 in $^{3}$ (58 L) BOLT ${ }^{\circledR}$ GGuns 1500LL at $2000 \mathrm{psi}$ air pressure, towed at $8 \mathrm{~m}$ depth. The data were sampled at $1 \mathrm{~ms}$ and recorded in SEG-D format. Shooting during the cruise was carefully carried out following established rules to avoid harming local marine mammals, using soft starts and monitoring the presence of marine mammals and turtles in the 


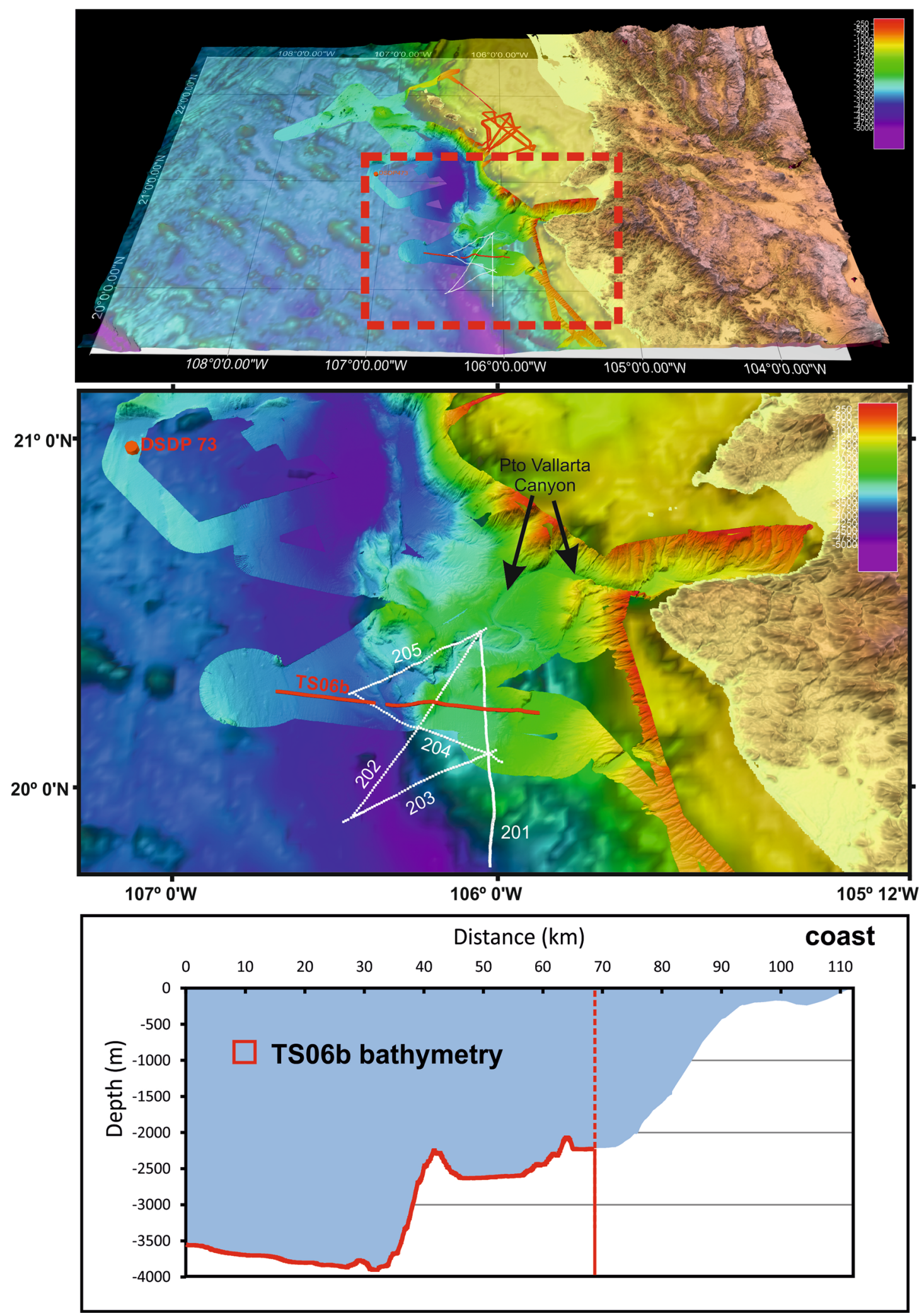


Figure 4

Processing flow applied to multichannel seismic profile TS06b

vicinity of the vessel, which caused us to stop shooting repeatedly.

To obtain the best seismic crustal images, several processing steps were applied to the seismic data to improve the seismic resolution and to enhance the signal to noise ratio. The real marine geometry has been calculated and added into the trace headers, using the real positioning information obtained from navigation files, which includes hydrophone and source GPS positions, channel number and shot identification number. The main applied processing steps include: (1) prestack signal enhancement (editing traces, mute and filtering), (2) deconvolution (18 ms gap and $360 \mathrm{~ms}$ length), to improve vertical resolution, (3) velocity analysis every $200 \mathrm{CMP}$, (4) Radon demultiple, to suppress multiple seafloor arrivals, (5) NMO correction and stack to increase the signal to noise ratio, and finally, (6) Kirchhoff time migration, which increases the horizontal resolution and collapse diffractions relocating in time the events. Time variant band pass filtering and different gains have been applied for final display. Details of parameters used during processing are shown in Fig. 4.

\section{Results and Discussion}

\subsection{General Description of the Profile}

The interpretation of the geodynamic and tectonic features imaged by seismic profile TS06b is placed within the general framework of the subduction of the oceanic Rivera plate beneath the NA plate, crossing the lower slope of the margin (see the synthetic bathymetric cross section in Fig. 3, third panel). Two large areas with different tecto-sedimentary features can be distinguished in the profile: the western area (from CDP 7000 to CDP 11000), formed by the subducting oceanic Rivera plate and sedimentary marine deposits above it; and the eastern area (from CDP 100 to CDP 7000), formed by the accretionary prism and the associated sedimentary basins belonging to the continental NA plate which overly the

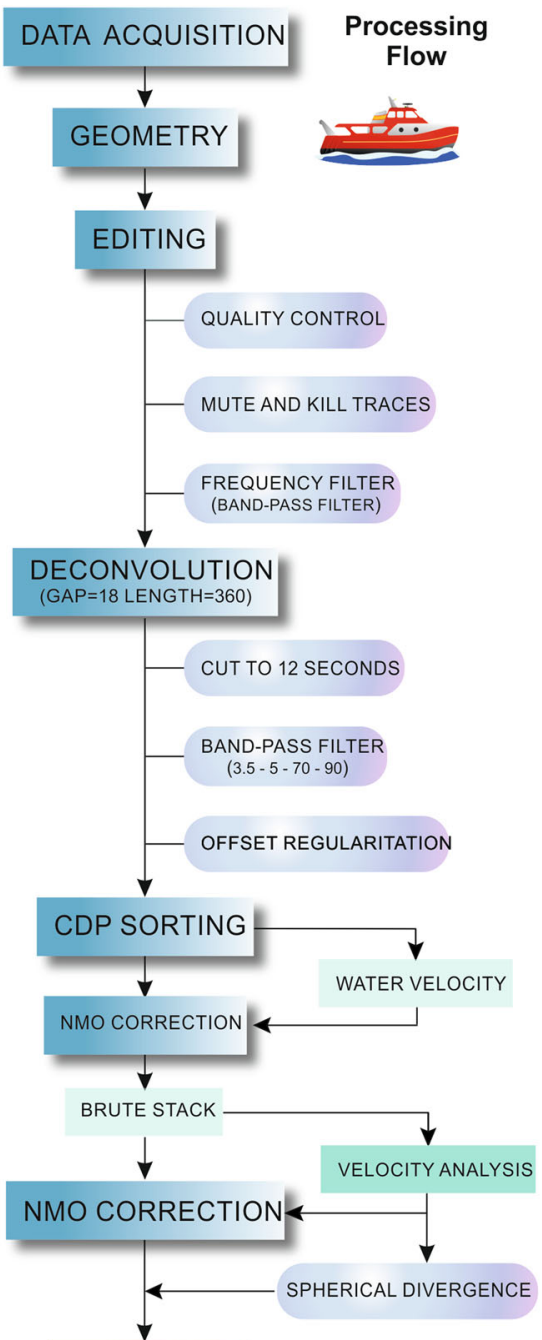

FINAL STACK

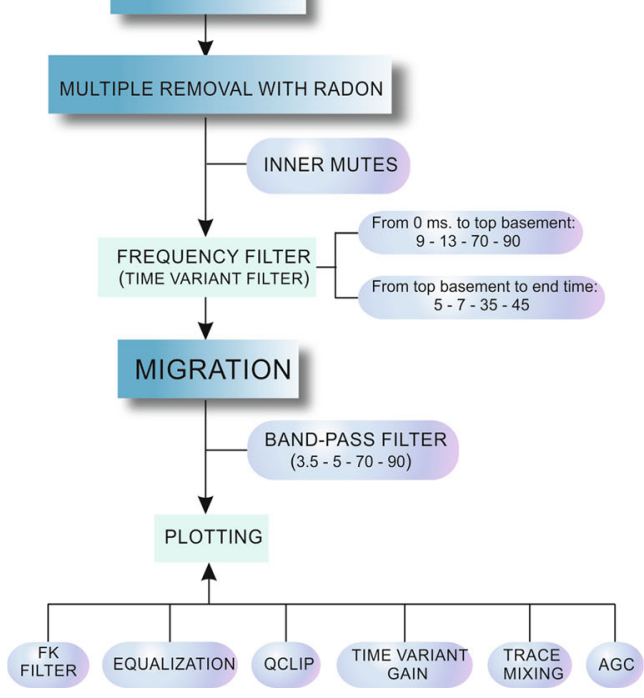




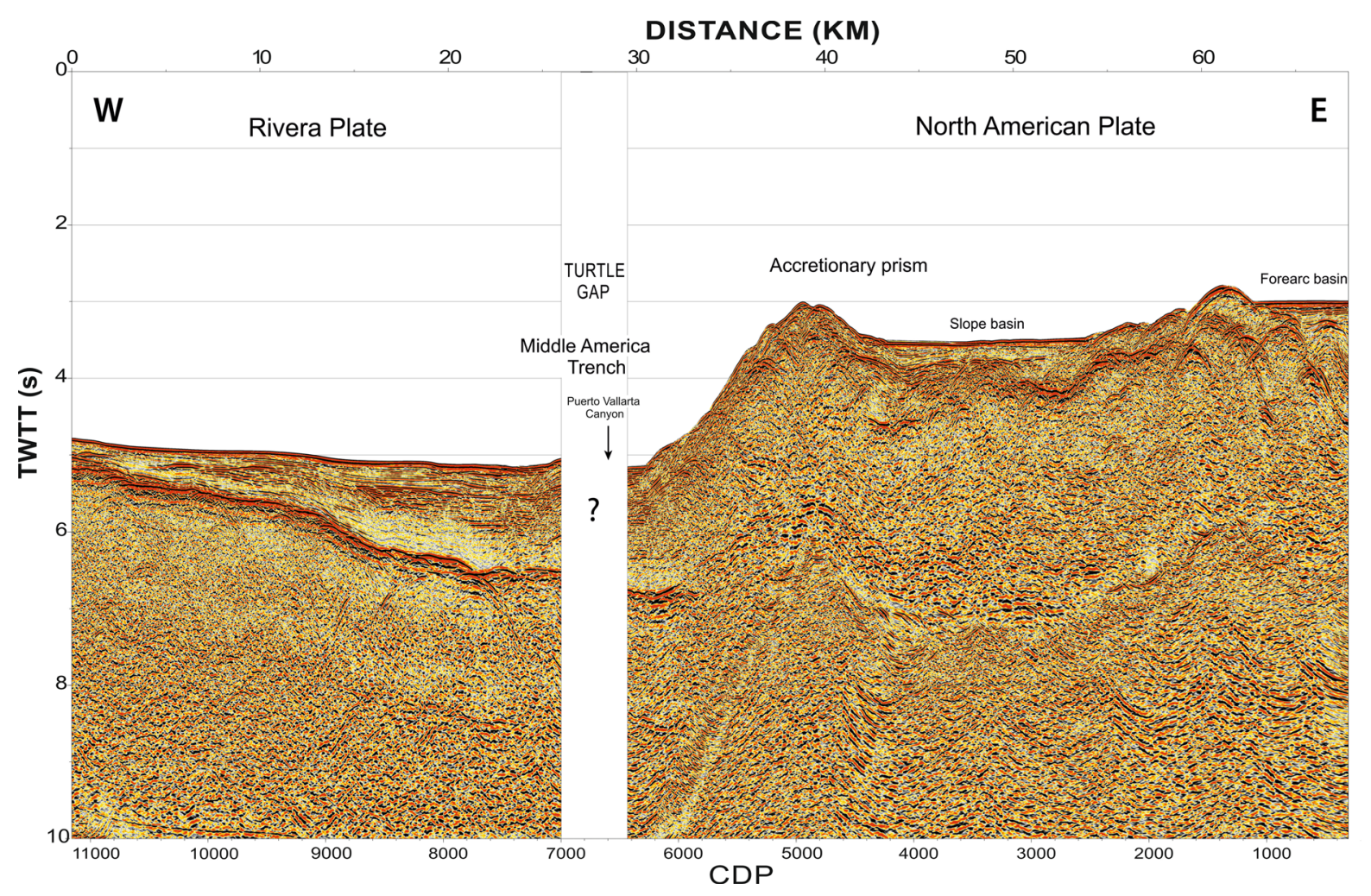

Figure 5

Time migration section of multichannel seismic profile TS06b after applying the processing flow of Fig. 4. See text for details

subducting oceanic plate. Both areas are delimited by a strong horizontal amplitude reflector, which marks the limit between the two tectonic plates, the interplate boundary (Fig. 5). This boundary can be followed almost continuously along the entire profile. Below the interplate reflector, at $7-8 \mathrm{~s}$ two-way travel time (twtt), the crust-mantle boundary (Moho) can be clearly distinguished along the profile as a discontinuous reflector that parallels, and is located $2 \mathrm{~s}$ twtt below, the interplate reflector (Fig. 6).

From west to east, the top of the Rivera plate imaged below the sedimentary cover indicates that the plate is entering at a gentle dip angle $\left(<10^{\circ}\right)$ in this part of the margin. We can distinguish normal faults, and the resulting horst and graben morphology, as a consequence of the extensional stresses produced as the plate bends down into the subduction zone (see from 0 to $25 \mathrm{~km}$ in Fig. 6).

Further to the east of the MAT, the top of oceanic basement may be traced continuously for about
$20 \mathrm{~km}$ beneath the accretionary wedge where the Rivera plate is covered by about $3 \mathrm{~s}$ (twtt) of sediments, indicating subduction-accretion in this part of the margin, which is in agreement with previous studies (e.g., BARTOLOME et al. 2011). A pull up image effect of the Rivera plate under the accretionary prism (from CDP 4000 to CDP 6000, see Fig. 5) is observed. This pull up image effect is not geologically real and is caused by the relative seismic velocity differences of the acoustic waves between the lower velocity water column, left of the accretionary prism, respect to the higher sedimentary velocity cover in the prism, and their consequent representation in time (twtt) causing what appears to be a structural high.

\subsection{Oceanic Crustal Structure}

The MAT imaged in the section TS06b is about $3900 \mathrm{~m}$ deep, only $400 \mathrm{~m}$ deeper than the surrounding regional bathymetric oceanic lithosphere 


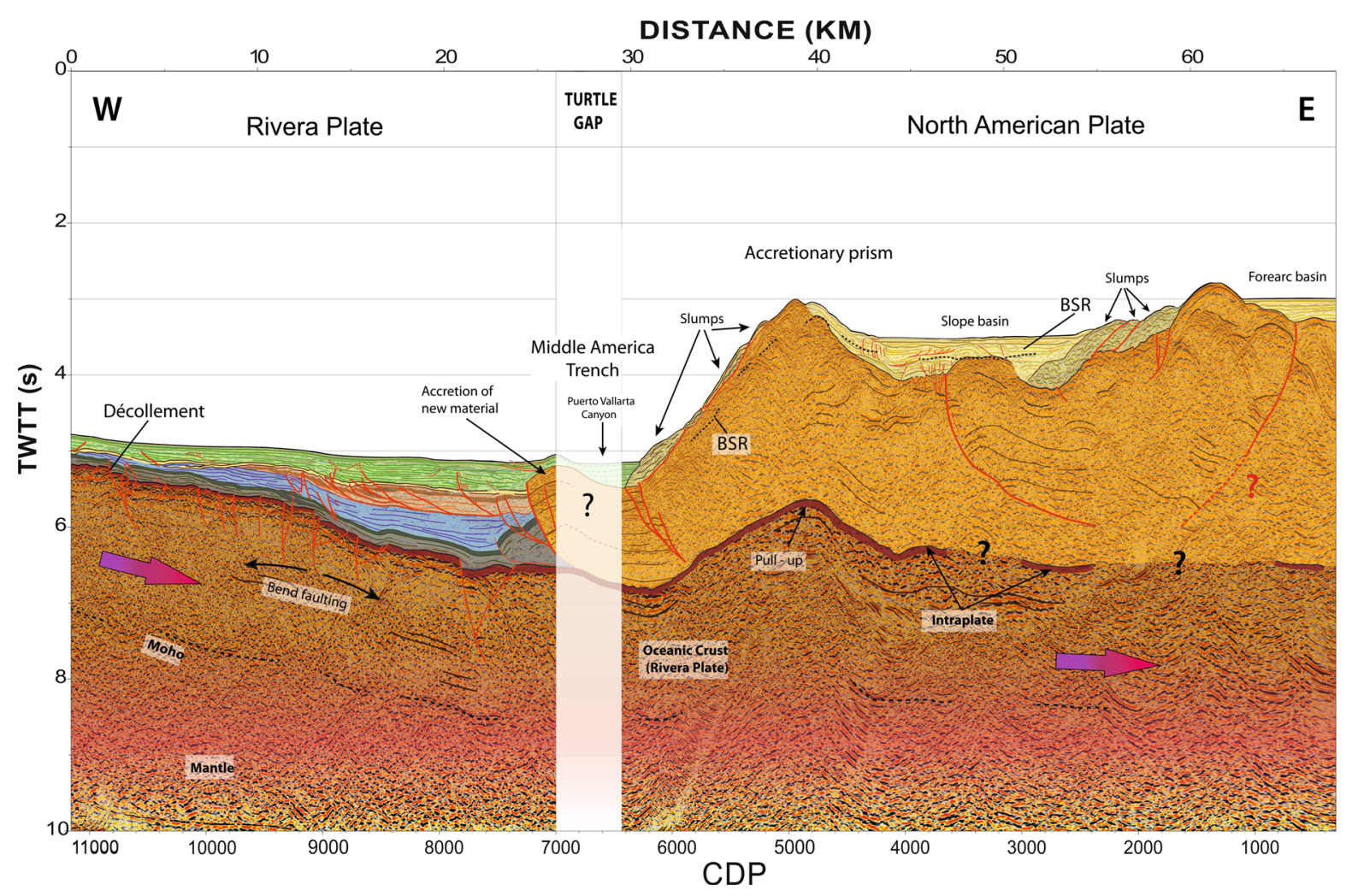

Figure 6

Interpretation of time migrated section TS06b, where the oceanic Rivera plate subducts beneath the NA plate. See text for details

(Fig. 3a). Sediment supply origin could be continental following the conclusions of Deep Sea Drilling Project (DSDP) 473. The trench bends sharply northward at $20^{\circ} \mathrm{N}$, increasing the obliquity of subduction north of this latitude. There are several factors controlling the depth of the trenches, but possibly the most important is the supply of sediment, which fills the trench and reduces the bathymetric expression of the trench. The deepest trenches in the world, in general, deeper than $8000 \mathrm{~m}$ are all nonaccretionary (no prism), such as the Mariana $(11,000 \mathrm{~m})$, Tonga $(10,800 \mathrm{~m})$, and Philippine $(10,500 \mathrm{~m})$ trenches. The age of the lithosphere at the time of subduction controls as well the depth of the trench: the older the seafloor (and cooler and thicker), the greater the subsidence of the trench. The slow convergence of the Rivera plate also causes the capacity of the convergent margin to dispose of (i.e., to subduct) sediment to be exceeded. Studies of the sediment fill in the northern part of the MAT are limited (e.g., Ross 1971; RenARd et al. 1980; Mercier de LÉPINAY et al. 1997). The Deep Sea Drilling Project (DSDP) and the Ocean Drilling Program (ODP) data in Mexico are restricted to two different areas. The first area is in front of Acapulco about $700 \mathrm{~km}$ further to the south of line TS06b. The second area is that of DSDP Site 473 drilled in 1978 (Fig. 3b) which is located about $70 \mathrm{~km}$ southwest of Islas Tres Marias and $90 \mathrm{~km} \mathrm{NW}$ of seismic line TS06b.

Sediment transport is controlled in the Jalisco Block by submarine landslides, debris flows and submarine canyons such as the Puerto Vallarta Canyon (see Fig. 3). Sediments are transported down the Puerto Vallarta Canyon and into the trench, but sediments have yet to completely fill the trench. In addition to sedimentation and age of the lithosphere, three tectonic processes control the trench-fill at convergent plate boundaries: subduction accretion, sediment subduction and tectonic (subduction) erosion. Which of these processes is dominant depends on the state of stress at subduction zone; when the 
interplate coupling (normal stress across the subduction zone) is low then sediment subduction operates. Either accretion or erosion occurs when coupling is high (Uyeda and KANAMORI 1979). As the Rivera plate is a young plate, the descent is more difficult because the plate is light and hot and the interplate coupling becomes strong, and due to the existence of an accretionary prism, we can then conclude that subduction accretion is the dominant process at this latitude at the foot of the margin along the lower slope and that it is more important than off Manzanillo. This is opposite of what MANEA et al. (2003) conclude in the Jalisco Block area inferring a sediment fill in the MAT close to zero from gravity anomalies, suggesting that the dominant process is the sediment subduction. The assumption of null fresh sediment fill is due to the lack of seismic data at the time of the publication, but now the shallow sedimentary structure of the Rivera plate is well imaged with profile TS06b. The sedimentary cover has strong reflectivity, generally subparallel, and their continuity can be followed for about $25-30 \mathrm{~km}$. Trench sediment thickness is about $1.6 \mathrm{~s}$ twtt, corresponding to a $2 \mathrm{~km}$ depth for an average sediment velocity of $2.5 \mathrm{~km} / \mathrm{s}$. The maximum thickness value of the trench-fill is compatible with previous works in the area based on seismic images (BARTOLOME et al. 2011, see Fig. 3 for location of the profiles) confirming a decreasing trend towards the south, with values of $2 \mathrm{~s}$ twtt in profile 205 and 1.5 twtt in profile 204, north and south of line TS06b, respectively. These deposits seem to be syn-tectonic to the normal faulting and subduction of the Rivera plate, mainly characterized by thrusts and reverse faulting. The sedimentary sequence can be divided into four subunits following their geometric relationships, presenting onlap, downlap and erosive truncations geometries (Fig. 7). This geometry would indicate different phases of sedimentation during the subduction of the Rivera plate, difficult to date due to a lack of information of wells, drills or cores in this unexplored area despite DSDP 473.

\subsection{Continental Structure}

East of the trench, the shallow morphology of the NA plate is represented by an accretionary prism formed by a sedimentary structure up to $4 \mathrm{~s}$ twtt of maximum thickness. This unit is characterized by a set of chaotic reflectors that lack lateral continuity (Fig. 8), indicating that the sediments of this unit have been highly deformed.

The top of the accretionary prism presents a sharp relief, forming two sediment filled basins (Fig. 8). The western basin, herein, referred to as the slope basin, is located in the center of the accretionary prism (between CDP 1600 and CDP 4800), and the sediments observed may be originated during the erosion of the accretionary prism. This took place during different episodes of uplift, generating slumps and normal faults related to gravitational movements that give rise to thrusts in the upper block (Fig. 8). The second basin, located on the eastern border of the profile (from CDP 1 to CDP 1200), is the forearc basin of the subduction system, whose sediments are onlaping the basement. Also, a system of slumps that reaches the base of the prism has been observed (from CDP 5000 to CDP 6400), covered by sediment units.

Three major zones of faulting can be identified in the accretionary wedge. The first one, located in the westernmost part (about CDP 7200), presents west vergence and constitutes the frontal thrust of the prism, being the boundary between the accretion prism and the sediments covering the Rivera plate (Fig. 8). The second fractured zone located in the center of the accretionary prism (around CDP 3600) has been interpreted as a thrust, with an East dipping orientation, which uplifts the top of the accretionary unit. The last major fracture is located in the eastern part of the profile at $65 \mathrm{~km}$ (about CDP 600) although other similar trending minor faults, $1.5 \mathrm{~km}$ to the west, could be also interpreted with a bathymetric escarpment of $160 \mathrm{~m}$. This fault, difficult to detect in the seismic profile, has been identified through the 3-D high-resolution bathymetry acquired during the TSUJAL seafloor ocean mapping survey (Fig. 9). The western side of this fault appears to be uplifted relative to the eastern side (being part the forearc basin) suggesting a thrust fault (or reverse fault) associated with the accretionary prism, however, it dips down to the west instead of the expected east direction. This fault might be a candidate to generate a tsunami if a large part of it broke at once, or a 

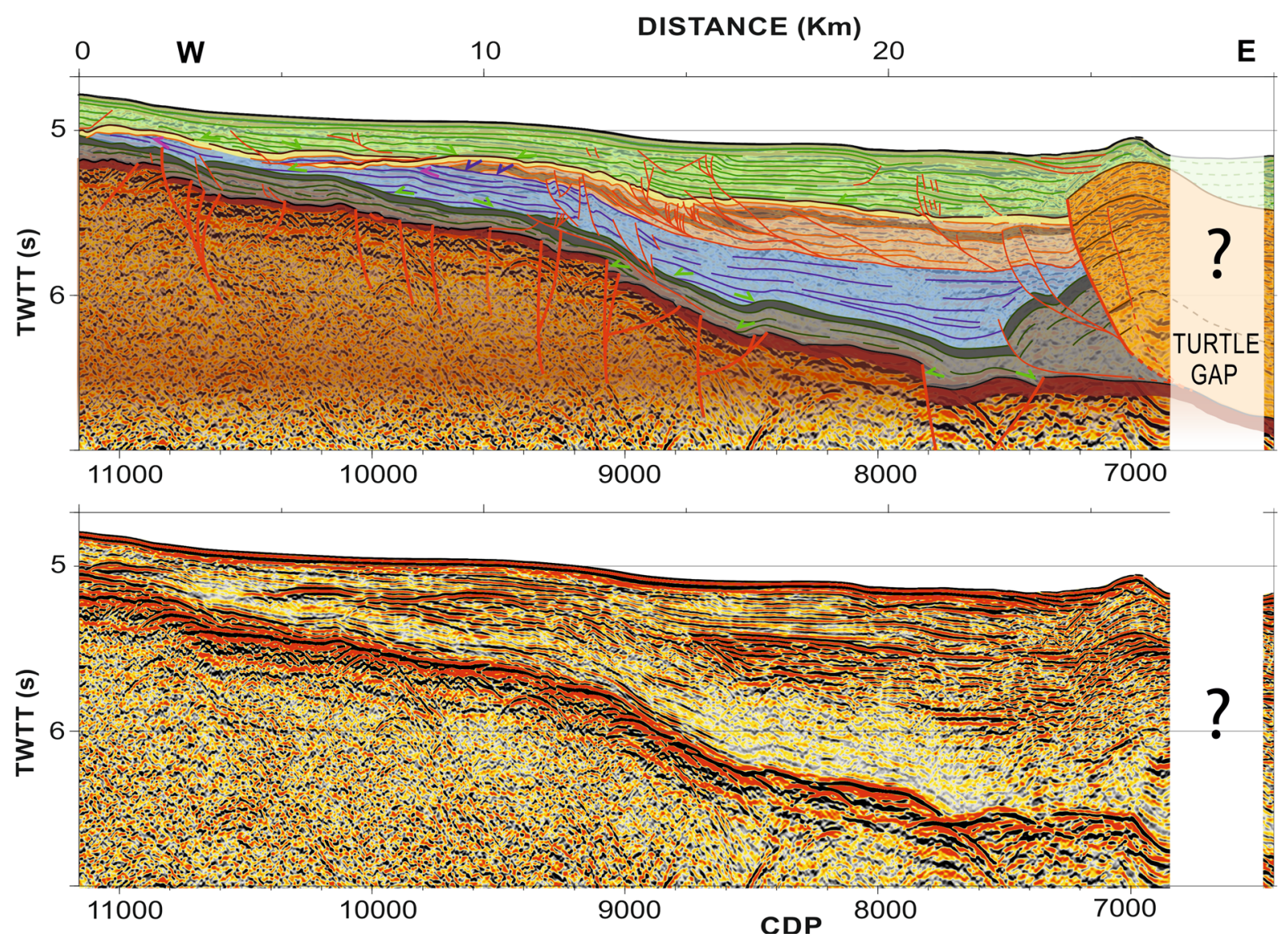

Figure 7

Up Interpretation of the oceanic Rivera plate section of profile TS06b. Onlap (green arrows), downlap (blue arrows) and erosional truncations (pink arrows) geometries are mixed along the sedimentary units. Note the normal faulting in the top of the oceanic crust below the sediments due to the bending of the plate during the subduction. Trench is filled by sediments about $1.6 \mathrm{~s}$ twtt of thickness, corresponding to a $2 \mathrm{~km}$ depth for an average sediment velocity of $2.5 \mathrm{~km} / \mathrm{s}$. Down multichannel seismic section of profile TS06b without interpretation

strong motion of the fault would produce sediment shaking which in turn could cause a landslide and a tsunami. Further bathymetric studies related with this regional fault should be conducted in the area for a tsunami risk assessment.

\subsection{Generation of Earthquakes}

Recent 2004 Sumatra-Andaman and 2011 Tohoku events violate the classical RUFF and KANAMORI (1980) direct relationship between convergence rate and age to the maximum earthquake magnitude (SHEARER and BürgmanN 2010). It is assumed that faster subducting lithosphere should increase friction at the interface, and that a younger subducting plate (more buoyant and lighter) is strongly coupled with the continental plate. Thus, both faster and younger plates increase the magnitude of the expected event. But the Mw 9.2 Sumatra earthquake occurred in an area with a low convergence rate $(3 \mathrm{~cm} /$ year $)$ and where the age of the subducting plate is 55-90 Ma old. The Mw 9 Tohoku event occurred in a $130 \mathrm{Ma}$ old subducting plate, which is older than most of the other ocean floors in the world, and where the convergence rate is $10 \mathrm{~cm} /$ year. Great earthquakes in the past like the $\mathrm{Mw} 9+$ Chile and Alaska earthquakes occurred on the plate boundary with a convergence rate of $11 \mathrm{~cm} /$ year and plate age of $20 \mathrm{Ma}$, and $6 \mathrm{~cm} /$ year and $40 \mathrm{Ma}$, respectively (KANAMORI 2006). 


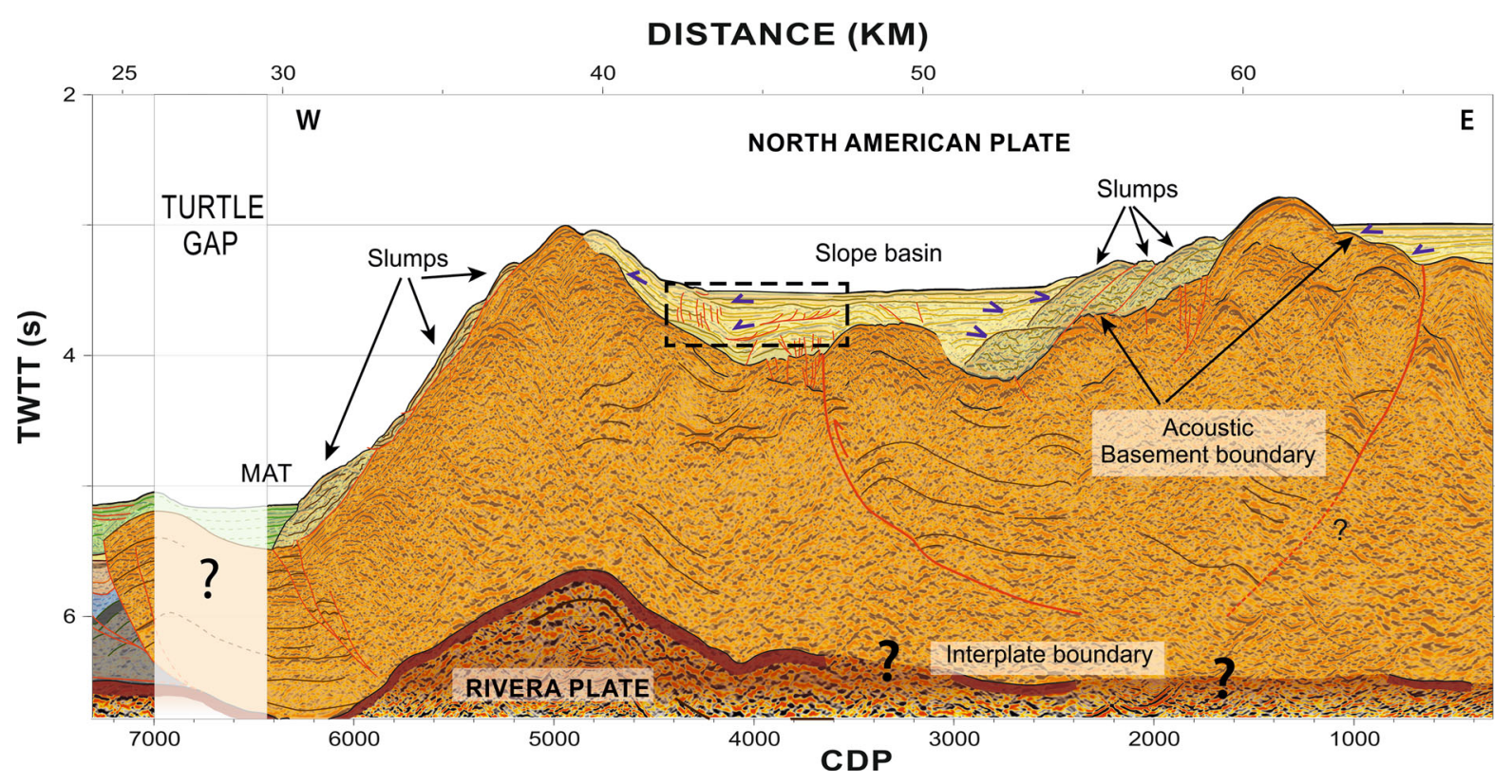

Figure 8

Accretionary prism, slope and forearc basins interpreted in multichannel profile TS06b. Basins show onlap (blue arrows) geometries. Dashed box may indicate a probably extensional gravitational collapse and the resulting thrust generation

Thus, new relationships are needed to relate the magnitude of an earthquake with geophysical parameters. For instance, both tectonic stresses and geometrical irregularities along the subduction interface have been empirically related to giant earthquakes ( $\mathrm{Mw} \geq 8.5$ ). Heuret et al. (2012) found a statistical relationship between the occurrence of subduction megathrust earthquakes and the combination of thick trench infill $(\geq 1 \mathrm{~km})$ and neutral upper plate strain. In fact, the combination of these two factors is more highly correlated with the occurrence than either factor alone. When the propagation of rupture in the trench-parallel direction breaks a larger number of thrust fault segments then the magnitude of a seismic earthquake increases. The propagation seems to be controlled by the distribution of geometrical irregularities and thick trench infill would represent the geometrical irregularities along the subduction interface. In other words, trench infill acting as a proxy for smoothing of subducting plate relief by sediment input into the subduction channel and facilitating propagation. Although statistics are difficult due to the limited number of large earthquakes, ScHoll et al. (2011) demonstrated that trench sectors with axial deposits thicker than $1.0 \mathrm{~km}$ are associated with the occurrence of an unusually high number of giants earthquakes $(67 \%$ of $\mathrm{Mw}>8.5$ in the Earth). Moreover, upper (in the Jalisco Block at the NA) plate strain would act as a proxy for the tectonic stresses applied to the subduction interface, and the tectonic stresses may be inferred from deformation in the back-arc. The propagation of an initial rupture to neighboring asperities is made difficult by compressive tectonics, easily associated with neutral back-arcs and never associated with extensional domains (HeURET et al. 2012). Recent GPS investigations found the Jalisco Block to be moving slowly ( $2 \mathrm{~mm} / \mathrm{year})$ to the southwest relative to NA plate (Selvans et al. 2011) or perhaps not even moving as an independent block. Consequently, considering these two factors together: almost neutral strain present in the Jalisco Block (upper plate strain) and large $(1.6 \mathrm{~km})$ sediment thickness observed in our seismic profile, the Jalisco Block has the geophysical favorable conditions to generate giant earthquakes. 


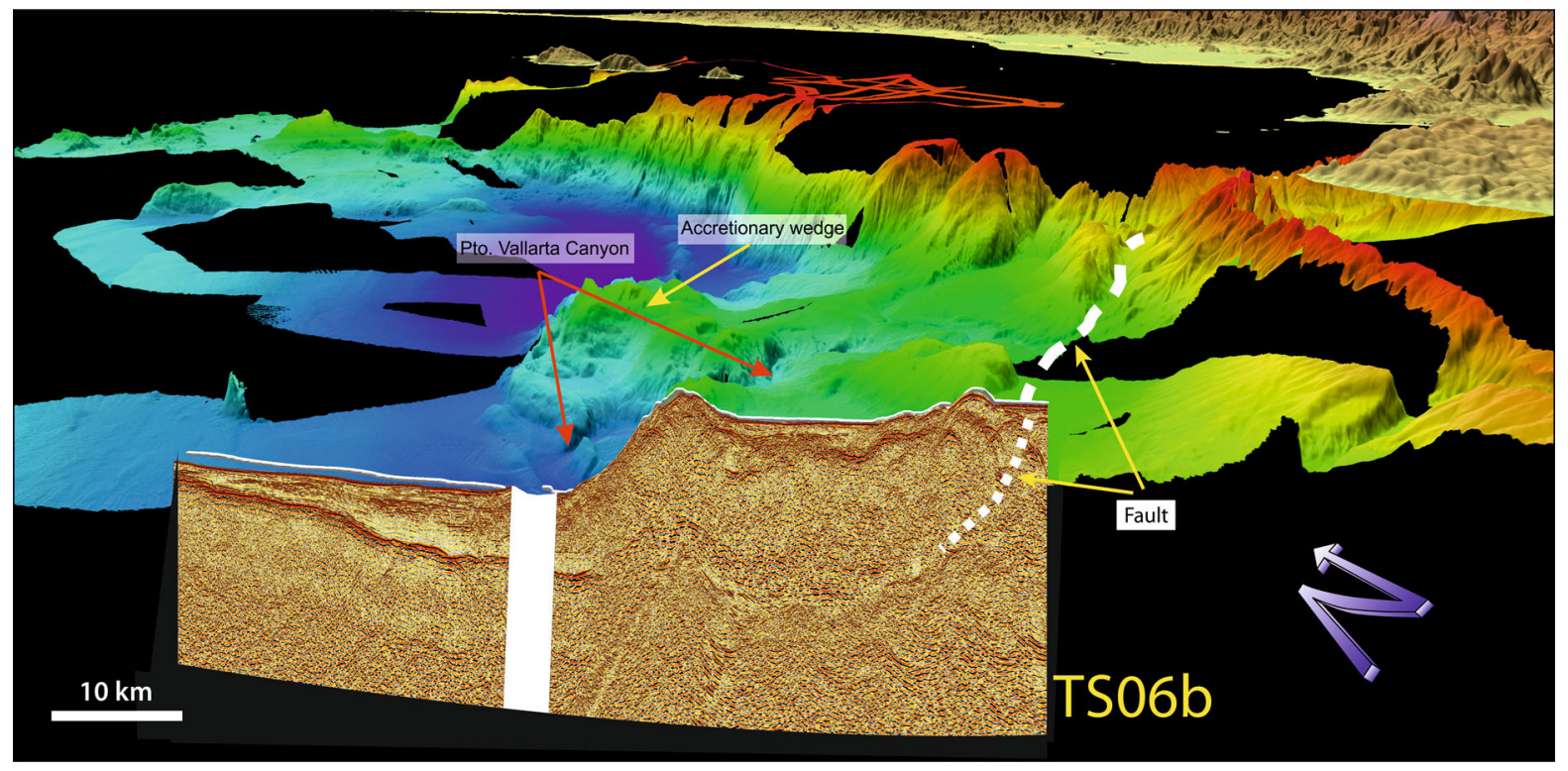

Figure 9

Location of the line TS06b in the 3-D high-resolution bathymetry map acquired during the TSUJAL survey. A major fault observed in the bathymetry grid, difficult to be interpreted in the seismic line, is shown in the eastern part of the profile

\subsection{Evidence for Gas Hydrates}

Gas hydrates have been recovered in sediment cores but their occurrence are usually inferred from a prominent identifiable high amplitude reflector in the seismic signal, commonly named bottom simulating reflector (BSR), although gas hydrates have also been encountered in regions without BSR (HAACKE et al. 2007). Multichannel seismic imaging is the best method to detect the presence of BSR. The BSR identified in seismic data in the offshore part of the Jalisco Block has been detected in the shallow continental domain and has a reversed polarity with respect to the seafloor. There are at least two types of origins for the occurrence of BSR. One is related to the presence of gas hydrates causing a negative acoustic impedance contrast between sediments containing gas hydrate extending from the seafloor to the BSR (which increases seismic velocity) and free gas underneath the gas hydrate stability zone (lower seismic velocity) in the pore space of accreted sediments (Fig. 10). Therefore, these BSR have reversed polarity. The other origin has been related with the strong positive acoustic impedance contrast between silicate rich sediments of the different diagenetic stages opal A, opal CT and quartz (KASTNER et al. 1977). Therefore, diagenesis-related BSRs have the same polarity as the seafloor reflection. The BSR identified in seismic data of the Jalisco Block have a reversed polarity with respect to the seafloor, and consequently, are related with the presence of natural gas hydrates.

The BSR imaged crosscuts sedimentary layers, and is easily recognized subparallel to the seaflor along the accretionary wedge and the forearc basin at 0.25-0.3 s (twtt) below the seaflor, extending for about $25 \mathrm{~km}$ along the profile (from CDP5800 to CDP2200). The BSR reflector is disrupted, and thus difficult to observe, by the presence of faulting, slumps and landslides, because gas hydrates may dissolve, and finally escape, causing the impedance contrast to disappear (Figs. 6, 10). This indicates that slope failure can cause the destruction of BSRs. But also rapid decompression of the underlying sediments in areas with occurrence of BSR (indicating methane hydrate) could lead to catastrophic release of methane and the resulting margin destabilization with the occurrence of mass transport deposits. 

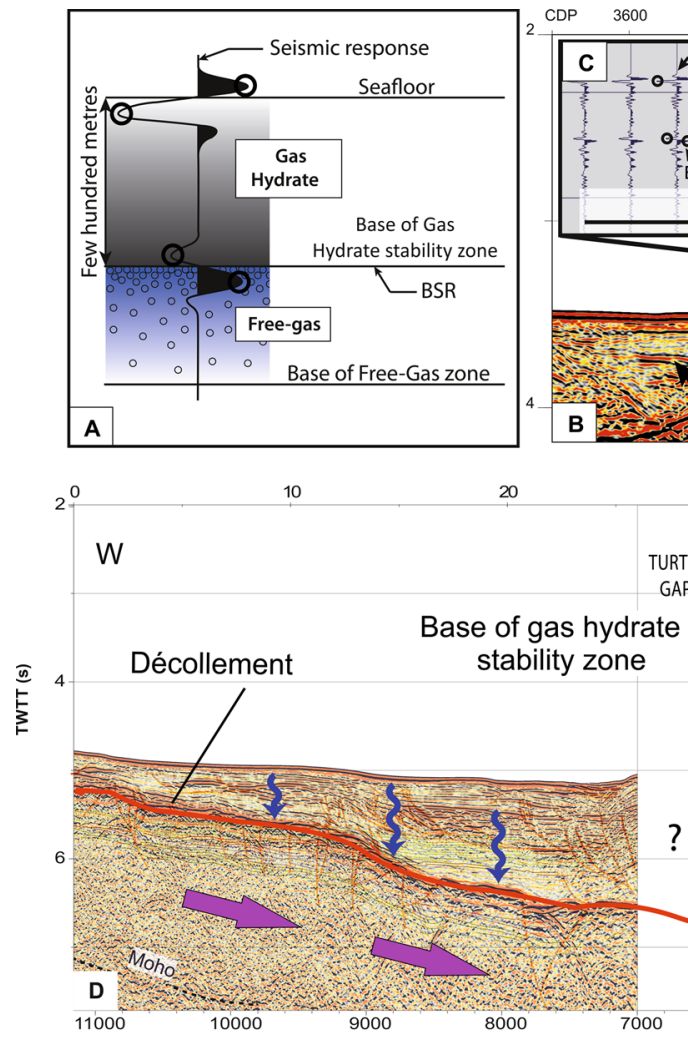

30

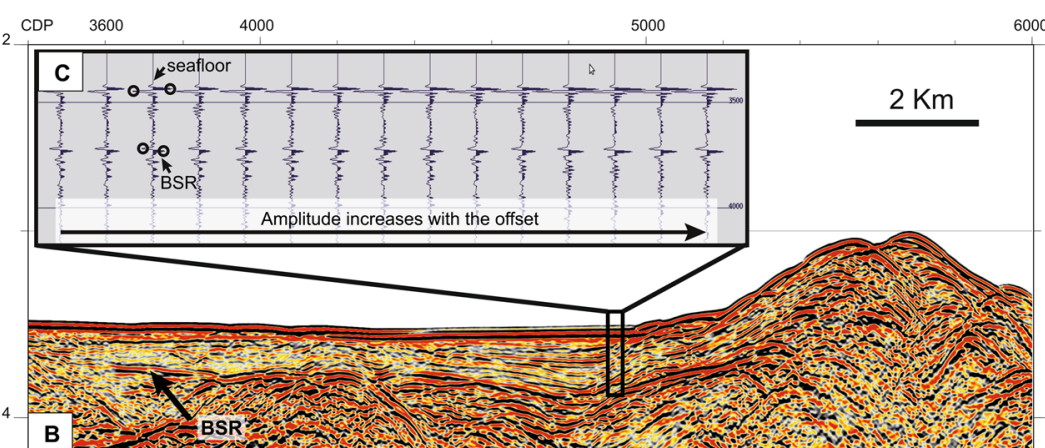

DISTANCE (KM)

50

60

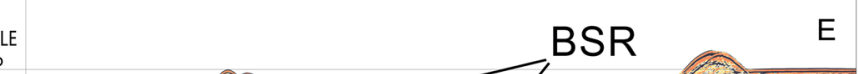

\section{E}

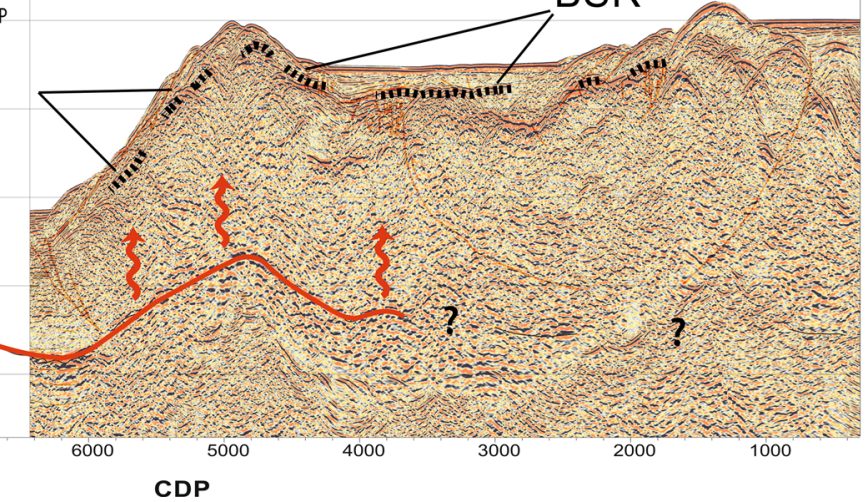

Figure 10

Gas hydrate occurrence in line TS06b. a Illustration of a submarine section containing the structure and location of gas hydrate (above) and free gas (below) of the bottom simulating reflector (BSR) (Image modified from HAACKE et al. 2007). b Detailed view of the accretionary wedge in profile TS06b showing a clear BSR at 200-300 twtt below the seafloor. c Traces (without AGC) of the CDP 4450 showing the high amplitude, reverse polarity and the amplitude increasing along offset of the BSR. d Structural interpretation of the line TS06b, from 2 to $8 \mathrm{~s}$ twtt, illustrating a theoretical transfer of fluids along the subduction plate and the formation of the gas hydrate

Significant evidence for the presence of gas hydrates, identified as BSR reflectors in multichannel seismic records, has been recognized in the same area in previous studies (BARTOLOME et al. 2011) and in the continental slope area of the southern Jalisco Subduction Zone off Manzanillo by BANDY and MorTERA GutiérRez (2012). Reflectors are found near Manzanillo at $0.4 \mathrm{~s}$ (two-way travel time) below the seafloor reflector. This result once again suggests that gas hydrates may exist in the continental slope region of the entire Jalisco Subduction Zone. However, more seismic reflection data needs to be collected to verify this assertion. These new findings are of value to evaluate the gas hydrate potential of the Jalisco
Subduction zone, an area that may contain a significant source of energy for the future (Fig. 11).

Deep faulting observed along the profile at the top of the oceanic Rivera plate can play an important role for circulation of fluids and the formation of gas hydrates in the accretionary prism, especially in two particular areas. First, in the décollement zone or basal thrust, which acts as a conduit for fluids producing wet sediments, and second in the accretionary wedge, where rapid rates of upward fluid flow and seafloor uplift occur (Fossen 2010, see Fig. 10). Therefore, it is more likely to occur serpentinization processes in the deeper part of the interplate contact due to the alteration process of olivine in the presence 

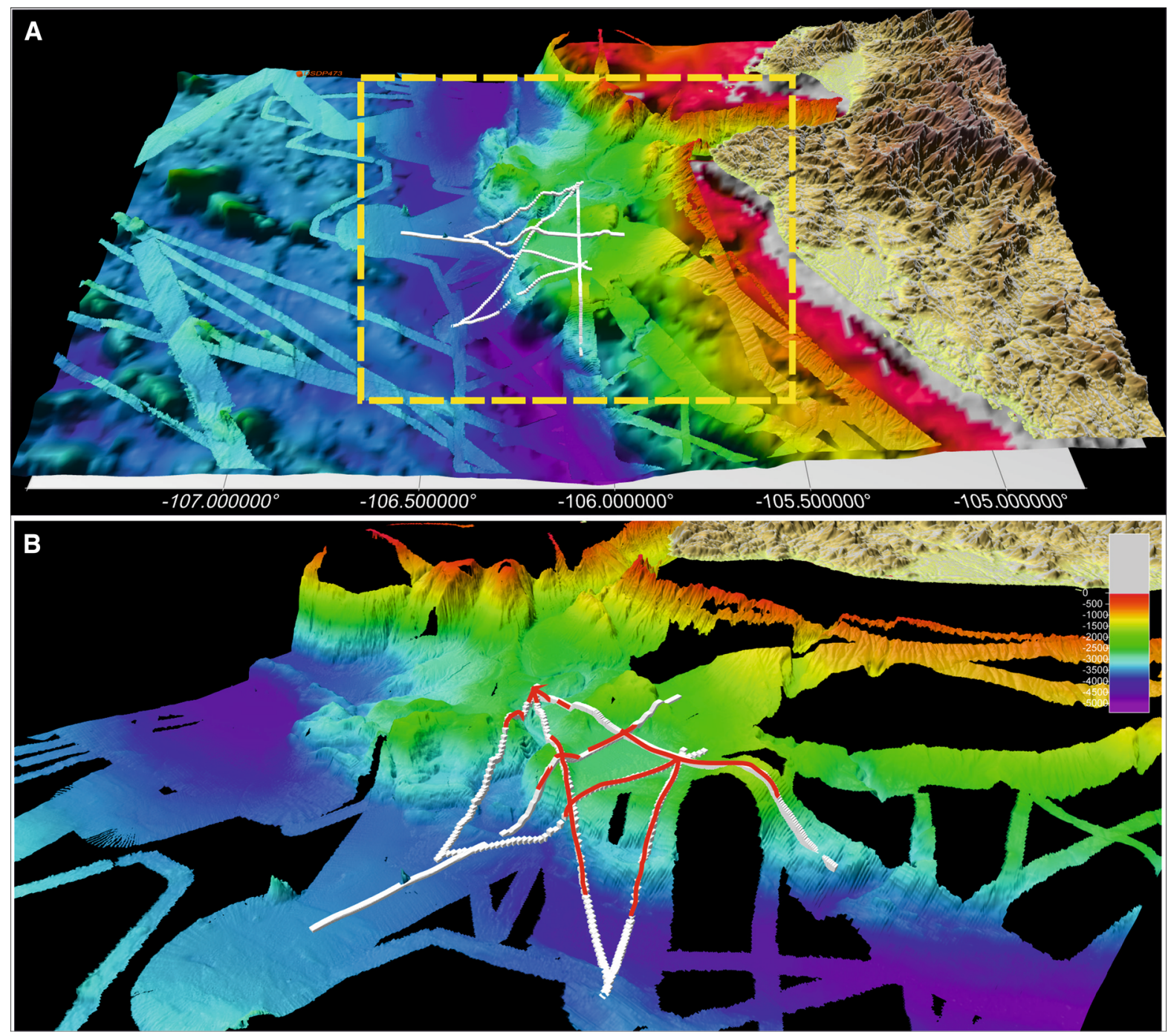

Figure 11

a Swath bathymetric data of TSUJAL and CORTES (BARTOLOME et al. 2011) surveys offshore the Jalisco Block. Thin white lines mark MCS profiles. b Red lines marks approximate location and distribution of BSR (and gas hydrates) offshore Puerto Vallarta

of water. In subduction zones, this process occurs along deep faults where oceanic plates enter, near the base of the mantle wedge at depths up to $150 \mathrm{~m}$ depth (MANEA and Manea 2011) and always greater than $10 \mathrm{~km}$. The décollement or basal thrust is identified in the interplate boundary, but the seismogenic zone is located in deeper areas of the subduction system not imaged by the TS06b. Subduction of serpentinized rocks enhances the generation of earthquakes and melting production in the mantle wedge, being able to influence the position of the melting front (and volcanic arc).

\section{Conclusions}

The western margin of Mexico, in general, and the Jalisco Block, in particular, is a region where several tectonic plates interact, turning it into one of the most active seismic and volcanic zones in the 
Americas. The investigation of subduction zones and associated seismogenic and volcanic areas becomes extremely important for the safety of people living in these areas. The reliability of a specific risk level regarding the future seismic activity in a region depends on the level of our understanding of the geodynamic processes, as well as the amount and quality of the available data. The structural and geometrical information provided by profile TS06b constitute an essential contribution to understand the geodynamic context of the area. Therefore, our work aimed to collect high quality geophysical data to make more reliable earthquake forecasts, which has important social implications on time-scales of months and years. The main conclusions are summarized as follows:

- Processing and interpretation of the line TS06b acquired during the TSUJAL survey has allowed to obtain, for the first time, a high quality seismic image of the entire internal structure of the Rivera Subduction Zone beneath North American plate. This paper shows the main structures in the Jalisco Block area at crustal scale, characterized by their geometry, morphology, dimension, deformation and fracturing of the internal structure, depth and their lateral continuity. In this way, accretionary prism, slope basins associated, forearc basin, crust-mantle boundary and interplate limit have been identified.

- Evidence of BSRs reflectors compiled using the available multichannel seismic data in the continental slope region of the entire Jalisco Subduction zone suggests that extensive gas hydrates accumulations may exist in this area.

- Normal faulting and the resulting horst and graben geometry are observed in the Rivera plate as a consequence of the bending of the plate as it begins to subduct beneath the NA plate. Fluid circulation of oceanic water can easily enter into the subduction system using these fault paths, helping the formation of gas hydrates and serpentinization.

- Subduction accretion is the dominant process at the Jalisco Block near Puerto Vallarta along the lower slope of the margin, in agreement with the occurrence of an accretionary prism and the young age of the Rivera plate
- The combination of a thick $(1.6 \mathrm{~km})$ sediment infill within the trench and an almost neutral strain in the Jalisco Block indicates that the area is prone to giant earthquake occurrence.

\section{Acknowledgments}

We acknowledge the Captain and crew of the RRS James Cook, the seismic UTM-CSIC technical team and Luis Ansorena for their professional work, and the officers and crew of the AMR Holzinger (Secretaría de Marina, Mexico) and CABO/UNAM J-GAP2013 Cruise (BO El Puma, Mexico) which made possible the success of the TSUJAL cruise. We gratefully acknowledge financial support from MINECO (Spain) through TSUJAL project (CGL2011-29474-C02-01) and "Ramon y Cajal" program (R. Bartolome), and from Mexico through CONACYT-FOMIXJAL 2008-96567 (2009); CONACYT-FOMIXJAL 2008-96539 (2009); CONACYT-FOMIXJAL 2010-149245 (2011); CONACyT-FOMIXJal (2012-08-189963) and also partial funding was provided by UNAM DGAPA Grant \#IN115513-3. We also gratefully acknowledge the support of the Mexican Instituto Oceanográfico del Pacífico in Manzanillo, Secretaría de Defensa Nacional, Unidad Municipal de Proteccion Civil y Bomberos (Puerto Vallarta), Unidad Estatal de Proteccion Civil y Bomberos (Nayarit State), Unidad Municipal de Proteccion Civil y Bomberos (Jalisco State), Reserva de la Biosfera (Islas Marías) CONANP-SEMARNAT, Órgano Desconcentrado de Prevención y Readaptacion Social de la SEGOB, Secretaría de Relaciones Exteriores for their help during all the cruise. This work was carried out within the Grup de Recerca de la Generalitat de Catalunya B-CSI (2014 SGR 940).

Open Access This article is distributed under the terms of the Creative Commons Attribution 4.0 International License (http:// creativecommons.org/licenses/by/4.0/), which permits unrestricted use, distribution, and reproduction in any medium, provided you give appropriate credit to the original author(s) and the source, provide a link to the Creative Commons license, and indicate if changes were made. 


\section{REFERENCES}

Allan, J.F. (1986). Geology of the Northern Colima and Zacoalco Grabens, southwest Mexico: Late Cenozoic rifting in the Mexican Volcanic Belt. Geol. Soc. Am. Bull., 97, 473-485.

Allan, J.F., Nelson, S.A., Luhr, J.F., Charmichael, I.S.E., Wopat, M., \& Wallace, P.J. (1991). Pliocene-Holocene rifting and associated volcanism in southwest Mexico: An exotic terrane in the making. In J. Dauphin \& B. Simoneit (Eds.) The Gulf and Peninsular Provinces of the Californias, Am. Assoc. Pet. Geol. Bull., Memoir 47, (pp. 425-445), Tulsa, AAPG.

Alvarez, R., \& Yutsis, V. (2015). The elusive Rivera-Cocos plate boundary: not diffuse. In T. J. Wright, A. Ayele, D.J. Ferguson, T. Kidane, \& C. Vye-Brown (Eds.), Magmatic Rifting and Active Volcanism, Geological Society, London, Special Publications, 420.

Andrews, V., Stock, J., Ramirez-VAzquez, C.A., \& Reyes-Davila, G. (2011). Double-difference relocation of the aftershocks of the Tecoman, Colima, Mexico earthquake. Pure and Applied Geophysics, 168, 1331-1338.

Argus, D.F., Gordon, R.G., Heflin, M.B., Chopo M.C., Eanes, R.J., Willis, P., Peltier, W.R., \& Owen, S.E. (2010). The angular velocities of the plates and the velocity of Earth's centre from space geodesy. Geophys. J. Int., 180, 913-960.

BANDY, W.L. (1992). Geological and Geophysical Investigation of the Rivera-Cocos Plate Boundary: Implications for Plate Fragmentation, Ph.D. Dissertation, Texas A\&M University, College Station.

Bandy W.L., \& Mortera Gutiérrez, C.A. (2012). Gas Hydrates in the southern Jalisco subduction zone as evidenced by bottom simulating reflectors in Multichannel Seismic Reflection Data of the 2002 BART/FAMEX campaign. Geofísica Internacional, 51(4), 393-400.

Bandy, W.L., \& Pardo, M. (1994). Statistical examination of the existence and relative motion of the Jalisco and Southern Mexico Blocks. Tectonics, 13(4), 755-768.

Bandy, W.L., Mortera-Gutierrez, C., Urrutia-Fucugauchi, J., \& HiLdE, T.W.C. (1995). The subducted Rivera-Cocos plate boundary: Where is it, what is it, and what is its relationship to the Colima rift?. Geophysical Research Letters, 22, 3075-3078.

Bandy, W.L., Michaud, F., Bourgois, J., Calmus, T., Dyment, J., Mortera-Gutiérrez, C.A., Ortega-Ramírez, J., Pontoise, B., Royer, J.-Y., Sichler, B., Sosson, M., Rebolledo-Vieyra, M., Bigot-Cormier, F., Díaz-Molina, O., Hurtado-Artunduaga, A.D., Pardo-Castro, G., \& Trouillard-Perrot, C. (2005). Subsidence and strike-slip tectonism of the upper continental slope off Manzanillo, Mexico. Tectonophysics, 398, 115-140.

Bandy, W.L., Michaud F., Mortera-Gutiérrez C.A., Dyment, J., Bourgois, J., Royer, J.-Y., Calmus, T., Sosson, M., \& OrtegaRAMIREZ, J. (2011). The Mid-Rivera-Transform Discordance: Morphology and tectonic development. Pure and Applied Geophysics, 168(8-9), 1391-1413. doi:10.1007/s00024-010-0208-8.

Bandy, W.L., Kostoglodov, V., Singh, S.K., Pardo, M., Pacheco, J., \& URrutia-Fucugauchi, J. (1997). Implications of the October 1995 Colima-Jalisco Mexico earthquakes on the Rivera-North America Euler vector. Geophys. Res. Lett., 24(4), 485-488.

Bartolomé, R., Dañobeitia, J.J., \& Córdoba, D. (2015). Seismic research in western Mexico, Sea Technology, 56, 10, 25-29.

Bartolome, R., Dañobeitia, J.J., Michaud, F., Córdoba, D., \& Delgado-Argote, L. (2011). Imaging the seismic crustal structure of the western Mexican margin between $19^{\circ} \mathrm{N}$ and $21^{\circ} \mathrm{N}$. Pure and Applied Geophysics, 168, 1373-1389. doi:10. 1007/s00024-010-0206-X.

Bourgois, J., \& Michaud, F. (1991). Active fragmentation of the North American plate at the Mexican Triple Junction Area off Manzanillo (Mexico). Geomarine Letters, 11, 59-65.

Dañobeitia, J.J., Cordoba, D., Delgado-Argote, L.A., Michaud, F., Bartolomé, R., Farran, M., Carbonel, M., NuñEz-Cornú, F., $\&$ the CORTES-P96 Working GRoup (1997). Expedition Gathers New Data on Crust Beneath Mexican West Coast. EOS, Trans. Am. Geophys. Union, 78(49), 565-572.

Dañobeitia J.J., Bartolomé, R., Nuñez-Cornú, F., Cordoba, D., Bandy, W., Prada, M., Nuñez, D., Castellón, A., \& Alonso, J.L. (2015). Crustal architecture at the collision zone between Rivera and North American plates at the Jalisco Block: TSUJAL project. Pure and Applied Geophysics, This volume.

DeMets, C., Gordon, R.G., Argus, D.F., \& Stein, S. (1994). Effect of recent revisions to the geomagnetic reversal time scale on estimates of current plate motions. Geophys. Res. Lett., 21(20), 2191-2194.

DeMets, C., Gordon, R.G., \& Argus, D.F. (2010). Geologically current plate motions. Geophys. J. Int., 181, 1-80.

DeMets, C., \& Traylen, S. (2000). Motion of the Rivera plate since 10 Ma relative to the Pacific and North American plates and the mantle. In L. Ferrari, J. Stock, \& J. Urrutia-FucuGAUCHI (Eds.), The Influence of plate interaction on postLaramide magmatism and tectonics in Mexico (pp. 119-159), Tectonophysics, 31(1-4).

Demets, C., \& Wilson, D. S. (1997). Relative Motions of the Pacific, Rivera, North American, and Cocos Plates Since 0.78 Ma. J. Geophys. Res, 102(B2), 2789-2806.

Fossen, H. (2010). Structural geology. Cambridge University Press. George, D.L., Yuen, D.A., Maruyama, S., \& Yanai, S.C. (2011). What mechanisms produce the tsunami of 2011 Tohoku Earthquake: Elastic deformation or landslides?, paper presented at Asia Oceania Geosciences Society Fall Meeting, Taipei, Taiwan.

GriLli, S.T., et al. (2012). Numerical simulation of the 2011 Tohoku tsunami based on a new transient FEM co-seismic source: Comparison to far- and near-field observations. Pure Appl. Geophys. doi:10.1007/s00024-012-0528-y.

HaAcke, R.R., Westbrook, G K., \& Hyndman, R.D. (2007). Gas hydrate, fluid flow and free gas: Formation of the bottom-simulating reflector. Earth and Planetary Science Letters, 261(3), 407-420.

Heuret, A., Conrad, C., Funiciello, F., Lallemand, S., \& Sandri, L. (2012). Relation between subduction megathrust earthquakes, trench sediment thickness and upper plate strain. Geophys. Res. Lett., 39, L05304. doi:10.1029/2011GL050712.

Johnson, C.A., \& Harrison, C.G.A. (1989). Tectonics and volcanism in central Mexico: A Landsat Thematic Mapper perspective. Remote Sens. Envir., 28, 273-286.

KANAMORI, H. (1977). Seismic and aseismic slip along subduction zones and their tectonic implications. In M. TALwani \& W.C. PItman III (Eds.), Island Arcs Deep Sea Trenches and Back-Arc Basins (pp. 163-174). Washington D.C., American Geophysical Union.

KANAMORI, H. (2006). Lessons from the 2004 Sumatra-Andaman earthquake. Philos. Trans. R. Soc. A., 364, 1927-1945.

Kastner, M., Keene, J.B., \& Gieskes, J.M. (1977). Diagenesis of siliceous oozes-I. Chemical controls on the rate of opal-A to 
opal-CT transformation an experimental study. Geochimica et Cosmochimica Acta, 41, 1041-1059.

Klitgord, K., \& MAMmerickx, J. (1982). Northern East Pacific rise: magnetic anomaly and bathymetric framework. J. Geophys. Res., 100, 24367-24392.

Kostoglodov, V., \& BAndy, W. (1995). Seismotectonic Constraints on the Convergence Rate between the Rivera and North America Plates. J. Geophys. Res., 100(B9), 17977-17989.

Khutorskoy, M.D., Delgado-Argote, L.A., Fernández, R., Kononov, V.I., \& Polyak, B.G. (1994). Tectonics of the offshore Manzanillo and Tecpan basins, Mexican Pacific, from heat flow, bathymetric and seismic data. Geofís. Intern., 33, 161-185.

Leon Soto, G., Ni, J.F., Grand, S.P., Sandovol, E., Valenzuela, R.W., Guzman Speziale, M., Gómez González, J.M., \& DomÍnguez Reyes, T. (2009). Mantle flow in the Rivera-Cocos subduction zone. Geophy. J. Int., 179, 1004-1012. doi:10.1111/j. 1365-246X.2009.04352.x.

Lonsdale, P. (1995). Segmentation and disruption of the East Pacific Rise in the mouth of the Gulf of California. Marine Geophysical Researches, 17, 323-359.

Manea, M., Manea, V.C., \& Kostoglodov, V. (2003). Sediment fill in the Middle America Trench inferred from gravity anomalies. Geofísica Internacional, 42(4), 603-612.

Manea, V.C., \& Manea, M. (2011). Flat-slab thermal structure and evolution beneath central Mexico. Pure and Applied Geophysics, 168(8-9), 1475-1487.

McCloy, C., Ingle, J. C., \& Barron, J. A. (1988). Neogene stratigraphy, foraminifera, diatoms, and depositional history of María Madre Island Mexico: Evidence of Early Neogene marine conditions in the southern Gulf of California. Marine Micropaleontology, 13, 193-212.

Mercier de Lepinay, B., Michaud, F., \& the Nautimat team (1997). Large Neogene Subsidence along the Middle America trench off Mexico $\left(18^{\circ}-19^{\circ} \mathrm{N}\right)$ : Evidence from Submersible Observations. Geology, 25(5), 387-390.

Michaud, F., Dañobeitia, J., Carbonell, R., Bartolomé, R., Cordoba, D., Delgado Argote, L., Núñez Cornú, F., \& Monfret, T. (2000). New insights into the subducting ocean crust in the Middle American Trench off western Mexico $\left(17^{\circ}-19^{\circ} \mathrm{N}\right)$. Tectonophysics, 318, 187-200.

Michaud, F., Dañobeitia, J., Bartolomé, R., Carbonell, R., Delgado Argote, L., Cordoba, D., \& Monfret, T. (2001). Did the East Pacific Rise subduct beneath the North American Plate (western Mexico)?. Geo-Marine Letters, 20 (3), 168-173.

Michaud, F., Mercier de Lepinay, B., Bourgois, J., \& Calmus, T. (1996). Evidence for active extensional tectonic features within the Acapulco trench fill at the Rivera-North America plate boundary, C.R. Acad. Sci., Paris, 321 série IIa, 521-528.

Minshull, T., Bartolomé, R., Byrne, S., \& Dañobeitia, J.J. (2005). Low heat flow from young oceanic lithosphere at the Middle America Trench off Mexico. Earth and Planetary Science Letters, 239, 33-41. doi:10.1016/j.eps1.2005.05.045.

Minster, J.B., \& JoRdan, T.H. (1979). Rotation vectors for the Philippine and Rivera plates (abstract). Eos Trans. Am. Geophys. Union, 60, 958.

Nixon, G.T. (1982). The relationship between Quaternary volcanism in central Mexico and the seismicity and structure of subducted ocean lithosphere. Geological Society of America Bulletin, 93, 514-523.

NúÑez-Cornú, F., Cordoba, D., Dañobeitia, J.J., Bandy, W., ORtiZ, M., Bartolome, R., NúÑEz, D., Zamora, A., Espíndola, J.M.,
Castellon, A., Escudero, C.R., Trejo, E., Escalona, F.J., Suárez, C., Mortera, C., \& TsuJal Working Group (2016). Geophysical Studies across Rivera Plate and Jalisco Block, MEXICO: TsuJal Project. Seism. Res. Lett, 87(1), 59-72. doi:10.1785/0220150144.

Nuñez-Cornú, F.J., Reyes-Dávila, G.A., Rutz, M., Trejo-Gómez, E., Camarena-García, M.A., \& Ramírez-VAZquez, C.A. (2004). The 2003 Armería, México earthquake (Mw 7.4): Mainshock and early aftershocks. Seism. Res. Lett, 75, 734-743.

Nunez-Cornu, F.J., Rutz, L.M., Marquez-Ramırez, V., SuarezPlascencia, C., \& Trejo-Gomez, E. (2011). Using an enhanced data set for reassessing the source region of the 2003 Armeria, Mexico, earthquake. Pure and Applied Geophysics, 168, 1293-1302.

Ochoa-Chavez, J.A., Escudero, C.R., Núñez-Cornú, F.J., \& BAndy, W.L. (2015). P-wave Velocity Tomography from Local Earthquakes in Western Mexico, Pure and Applied Geophysics, This volume.

OKAL, E.A., \& Borrero, J.C. (2011). The "tsunami earthquake" of 22 June 1932 in Manzanillo, Mexico: Seismological study and tsunami simulations. Geophys. J. Intl, 187, 1443-1459.

Pardo, M., \& Suárez, G. (1995). Shape of the subducted Rivera and Cocos plates in southern Mexico: Seismic and tectonic implications. J. Geophys. Res, 100, 12,357-12,373.

Peláez Gaviria, J.R., Mortera Gutiérrez, C.A., Bandy, W.L., \& Michaud, F. (2013). Morphology and magnetic survey of the Rivera-Cocos plate boundary of Colima, Mexico. Geofisica Internacional, 52(1), 73-85.

Quintanar Robles, L., Rodriguez-Lozoya, H.E., Ortega, R., Gomez-Gonzalez, J.M., Dominguez, T., Javier, C., Alcantara, L., \& Rebollar, C.J. (2011). Source characteristics of the 22 January $2003 M(w)=7.5$ Tecoman, Mexico, earthquake: New insights. Pure and Applied Geophysics, 168, 8-9, 1339-1353.

Ramírez-Herrera, M.T., Kostoglodov, V., \& Urrutia-Fucugauchi, J. (2011). Overview of recent coastal tectonic deformation in the Mexican subduction zone. Pure Appl. Geophys., 168, 1415-1433. doi:10.1007/s00024-010-0205-y.

Renard, V., Aubouin, J., Lonsdale, P., \& Stephan, J.F. (1980). Premiers resultants d'une etude de la fose d'Amerique Central au sondeur multifaisceaux (Seabeam). Geologie Marine, C.R.Acad. Sci., 291, Sér. D, 137-142.

Ross, D.A. (1971). Sediments in the northern Middle America trench. GSA Bulletin, 82, 303-322.

RufF, L.J., \& KANAMORI, H. (1980). Seismicity and the Subduction Process. Phys. Earth. Planet. Inter., 23, 240-252.

SANDwEll, D. T., \& SMith, W.H.F. (2009). Global marine gravity from retracked Geosat and ERS-1 altimetry: Ridge Segmentation versus spreading rate. J. Geophys. Res, 114, B01411. doi:10. 1029/2008JB006008.

Selvans, M., Stock, J.M., DeMets, C., Sanchez, O., \& MarquezAzuA, B. (2011). Constraints on Jalisco Block Motion and Tectonics of the Guadalajara Triple Junction from 1998-2001 Campaign GPS Data. Pure and Applied Geophysics, 168(8-9), 1435-1447.

Scholl, D.W., KiRBY, S.H., \& von Huene, R. (2011). Exploring a link between great and giant megathrust earthquakes and relative thickness of sediment and eroded debris in the subduction channel to roughness of subducted relief. Abstract TI4B-01 presented at 2011 Fall Meeting, AGU, San Francisco, Calif., 5-9 Dec.

SheARER, P., \& Bürgmann, R. (2010). Lessons learned from the 2004 Sumatra-Andaman megathrust rupture. Annu. Rev. Earth Planet. Sci., 38, 103-131. 
Singh, S.K., Ponce, L., \& Nishenko, S. (1985). The great Jalisco, Mexico earthquake of 1932: subduction of the Rivera plate. Bull. Seismic. Soc. Amer., 75, 1301-1313.

SuÁrez, G., Jaramillo, S.H., \& Bandy, W.L. (2013). Relative motion between the Rivera and North American plates determined from the slip directions of earthquakes. Pure and Applied Geophysics, 170, 2163-2172. doi:10.1007/s00024013-0667-9.

Uyeda, S., \& KanAmori, H. (1979). Back-arc opening and the mode of subduction. J. Geophy. Res, 84, 1049-1061.
Yagi, Y., Mikumo, T., Pachecho, J., \& Reyes, G. (2004). Source Rupture Process of the Tecoman, Colima, Mexico Earthquake of 22 January 2003, Determined by Joint Inversion of Teleseismic Body-Wave and Near-Source Data. Bull. Seism. Soc. Am., 94, 1795-1807.

Yang, T., Grand, S.P., Wilson, D., GuZman-Speziale, M., GomeZGonzalez, J.M., Dominguez-Reyes, T., \& Ni, J. (2009). Seismic structure beneath the Rivera subduction zone from finite-frequency seismic tomography. J. Geophys. Res., 114, B01302. doi:10.1029/2008JB005830.

(Received August 19, 2015, accepted June 10, 2016, Published online June 24, 2016) 